TITLE:

\title{
Angular Momentum Transfer in Dynamically Collapsing Gaseous Disks(Abstract_要旨)
}

$\operatorname{AUTHOR}(S)$ :

Nomura, Hideko

\section{CITATION:}

Nomura, Hideko. Angular Momentum Transfer in Dynamically Collapsing Gaseous Disks. 京都大学, 2001, 博士(理学)

ISSUE DATE:

2001-03-23

URL:

http://hdl.handle.net/2433/150830

RIGHT: 
氏 名野离村 英英

学位(専攻分野) 博 士 (理 学)

学位記番号理博 第 2298 号

学位授与の日付平成 13 年 3 月 23 日

学位授与の要件：学 位 規 則 第 4 . 条第 1 項 該 当

研究科. 専攻理学研究科物理学. 宇宙物理学専攻

学位論文題目 Angular Momentum Transfer in Dynamically Collapsing Gaseous Disks

（動的に収縮するガス円盤における角運動量輸送）

論文調査委員 助教授 嶺重 慎教授柴田一成教. 授舞原俊憲

論文内容 の 要 旨

申請者は，分子雲が重力収縮して星形成に至る過程のうち，原始星の中心核が形成されるまでのガス雲進化を，世界で初 めて粘性・重力トルクによる角運動量輸送を考慮した自己相似解の手法により明らかにし，角運動量輸送の星形成活動への 寄与を考察した。

分子雲が重力収縮して原始星を形成する際，あとから降り積もるガスは平均的に角運動量をもっているため，星周円盤と よばれる回転円盤を形成する。この星周円盤中の角運動量は様々な星形成活動に寄与する重要な物理量の1つであるが，そ の輸送機構は未だ論争中の課題である。申請者は，問題解明への第一歩として角運動量輸送機構をモデル化することにより， 原始星コア形成前の暴走的収縮期における円盤中の角運動量輸送を，自己相似解の手法により調べた。角運動量輸送機構と しては, 乱流に起因する粘性と，自己重力不安定によって成長する密度ゆらぎに起因する重力トルクを考虑した。なお，乱 流の渦の大きさは円盤の厚み以下, 速度は音速以下とし, 密度ゆらぎのスケールは重力不安定な最大波長を用いた。

こうして実際に相似空間での流体方程式を半解析的に解くことにより，申請者はガス円盤の構造を解いた。その結果，面 密度, 動径方向の速度は角運動量輸送なしの場合とほほ同じであったが, これは暴走的収縮期に円盤は回転平衡でないため である。一方，回転速度には角運動量輸送の効果がはっきりと現れた。すなわち，粘性・トルクが効くほど角運動量が効率 良く外向きに輸送され，その結果円盤内部の回転速度はより小さくなった。また，乱流粘性，重力トルクによる輸送を比較 すると，後者がより効率的に働く傾向となることも判明した。

では, 重力トルクが乱流粘性よりも効率がいいのはなぜだううか。そこで申請者は両者の大きさを比較し, その物理的意 味を考察した。円盤面垂直方向の静水圧平衡や，业音速乱流，円盤は回転平衡ではないことを仮定すると，乱流による粘性 係数には上限が与えられる。一方, 重カトルクによる輸送を表す粘性係数は, 熱エネルギーと重力エネルギーの比を表す $\mathrm{Q}$ 值という無次元量を用いて表される。申請者は実際に円盤の $\mathrm{Q}$ 值を計算し，暴走的収縮期においては常に $\mathrm{Q}<1$ である こと，すなわち重力過程が熱過程に卓越して働いて自己重力不安定を引き起こし，密度ゆらぎが成長して重力トルクが効率 的に㗢くことを明確に示した。

ついで申請者は，暴走的収縮期の角運動量輸送の星形成活動への寄与を考察した。時間を原始星期（Class 0)の寿命で ある一万年, 速度として分子雲内の音速をとって円盤の質量を計算すると, 円盤質量は太陽質量の0.6倍, すなわち $\mathrm{T}$ タ リ型星の質量程度となる。しかしながら円盤の角運動量は，Tタウリ型星の角運動量を遥かに凌駕する。これより円盤の角 運動量の大部分は暴走的収縮期後，T夕ウリ型星形成前の降着期に輸送されると結論づけた。さらに,コアに持ち込まれる 角運動量を調へてみると，輸送なしの場合と比べ最大で $80 \%$ 減少しており，角運動量輸送は原始星コア形成に大きな影響を 及ばすことがかかった。 


\section{論文審査 の 結 果 の 要旨}

星形成過程の解明は現代天文学の大きな課題である。星は分子雲中の高密度領域の重力收縮により形成される。その重力 収縮過程の研究は，20世紀半ばより数値計算・自己相似解を通して進められ，〈わしい崩壊のようすが明らかにされてきた。 それによると自己重力ガス雲の収縮過程は，(1)原始星コアが形成されるまでの暴走的収縮期と，(2)コアができてからの準静 的収縮期の，二つの段階にわけられることが自己相似解で明らかにされている。実際，自己重力不安定ガ入雲の重力崩壞の シミュレーション研究は，星ガス雲内の密度や収縮速度の動径方向分布は自己相似的に進化し，暴走的収縮期の中心密度の 上昇，原始星コアの形成を経て，そのコアへの降着がおこる姿を描き出している。

しかしながらこれまでの解析の多くは，回転の効果を全く取り入れないか，とりいれても角運動量の輸送まで議論できな い形式のものであった。一方，最近の高分解能電波観測は，高密度領域中心部の星周円盤が回転しながら重力収縮する様子 を明らかにしている。すなわち現実的な星形成理論を構築するには，回転角運動量およびその輸送の効果をきちんと評価す ることが本質となる。申請者の研究はその点に注目し，世界で初めて暴走的収縮期における角運動量輸送をきちんと取り扱 った点に独創性があり，極めて重要な研究といえる。

一般に球対称ガス雲の自己相似変数は，重力定数 $\mathrm{G}$ と音速 (等温ガス雲を仮定)という二つの定数を使って表現され， その変数を使うと, 質量保存の式と運動方程式の二つの偏微分方程式は二本の常微分方程式に書き換えられる。角運動量も 同じ変換則をもつので, 回転の効果を取り入れるのは容易である。さらに角運動量輸送機構である乱流粘性と重力トルクを, 自己相似方程式を構成するようにモデル化することにより，初めて目的が達成される。こうして導出された常微分方程式を， 中心部で質量分布の特異点がなく収縮速度がゼロになるという境界条件の下で解くと, 暴走的収縮期の解が得られる。自己 相似方程式は各変数が複雑にからみあっており解くのは困難を極めるが, 申請者は丁寧に数值的にとき，重力トルクが乱流 粘性に卓越すること，角運動量輸送は原始星コア形成に大きな影響を及ぼすこと等を世界で初めて明らかにした。

今回の解析は，今まであまり研究が進んでいなかった暴走的収縮期における角運動量輸送という問題に一石を投じたもの である。磁場の効果を十分吟味していないなど，幾分理想化された状況を扱っているものの，そこから得られた成果は，今 後の数值シミュレーション等を通じて，よりいっそう精密化されて発展されるものと期待される。したがって本論文は当該 分野における極めて重要な成果と位置づけられる。よって，本申請論文は，博士（理学）の学位論文として価值あるものと 認めた。なお，本論文に報告されている研究業績を中心とし，これに関連した研究分野について口頭試問を行った結果，合 格と認めた。 